\title{
Evaluation of kinetic models for tearing textile dyeing wastewater using UASB reactor
}

\author{
G.Gnanapragasam ${ }^{1}$, V.Arutchelvan ${ }^{2}$ L.Soundari ${ }^{1}$, C.S.Maneeshkumar ${ }^{1}$ \\ ${ }^{I}$ Department of Civil Engineering, IFET College of Engineering, Tamilnadu, India. \\ ${ }^{2}$ Department of Civil Engineering, Annamalai University, Annamalainagar-608002, Tamilnadu, India. \\ Corresponding Author: G.Gnanapragasam ${ }^{1}$
}

\begin{abstract}
In this study the wastewaters from textile dyeing industries and tapioca starch (SAGO) were combined for the treatment using two-phase Upflow Anaerobic Sludge Blanket (UASB) reactor. The system was inoculated with seed sludge from the anaerobic digester treating sago wastewater. The processes were carried out by feeding the combined wastewater at different mixing proportion with COD ranging from 5200 to 6320 $m g L^{-1}$. The maximum COD conversion was about $53.1 \%$ in acidogenic reactor and $88.5 \%$ in methanogenic reactor. The kinetic values obtained for Haldane's model $a, b$ and $c$ is 0.034, 19 and 8031, for modified StoverKincannon model is $R_{\max }=3.48 \mathrm{gL}^{-1} \mathrm{~d}^{-1}$ and $K_{B}=7.77 \mathrm{gL}^{-1} \mathrm{~d}^{-1}$ and for Grau second-order model the values of $a$, and $b$ were found to be 0.197 and 1.42. Among the other three kinetic models, Grau second order model and Stover-Kincannon model were observed to be the preeminent model for predicting the performance of two phase hybrid UASB reactors for treating combined real textile dyeing and sago wastewater with higher average regression coefficients $\left(R^{2}=0.979\right)$.
\end{abstract}

Keywords: Textile dyeing effluent, mixing ratio, sago, kinetic, UASB.

Date of Submission: 10-07-2017

Date of acceptance: 22-07-2017

\section{Introduction}

Textile processing industries produce high quantities of effluent with varying composition depending upon the wet process employed (Anderson et al. 1996). The textile industry consumes large amount of water, energy and auxiliary chemicals. In India, an average mill producing 60-104 $\mathrm{m}$ of fabric per day is likely to discharge approximately 1.5 million liters per day of effluent and the wastewater is being discharged into natural water bodies without proper treatment. Considering both the volume generated and the effluent composition, the textile industry wastewater is rated as the most polluting among all industrial sectors (Arslan et al. 2002). Important pollutants in textile effluent are mainly recalcitrant organics, color, toxicants and inhibitory compounds, surfactants, chlorinated compounds (AOX), $\mathrm{pH}$ and salts. Dyes are synthetic organics and generally have a complex chemical structure. They are xenobiotic in biotic environments and hence show persistence to biodegradation in nature. Apart from the aesthetic deterioration of the natural water bodies, dyes also cause harm to the flora and fauna in the natural environment (Basibuyuk and Forster 1997; Bhunia and Ghangrekar 2008). Physico-chemical methods, such as adsorption, coagulation- flocculation, membrane filtration and advanced oxidation, can be very effective for the removal of the colour in wastewaters but these processes merely transfer the pollutants from one phase to another. On the other hand, biological processes provide a low cost and efficient alternative for simultaneous colour and organic matter removal. However, complete dye degradation in wastewater treatment plants based only on aerobic processes is difficult to achieve since the main mechanism responsible for colour removal is adsorption onto the sludges (Buyukkamaci and Filibeli 2002). Anaerobic treatment is widely employed for treatment of most of the industrial wastewater containing high concentrations of soluble organic matter. The Upflow Anaerobic Sludge Blanket (UASB) reactor system developed by Lettinga and his co-workers in the 1970s has received widespread acceptance and has been successfully used to treat a variety of biodegradable industrial wastewaters. UASB reactors belong to the group of high-rate anaerobic reactors with a sludge bed. Granular biomass with high methanogenic activity and excellent settling properties can be cultivated in these reactors. The limitations of UASB reactors are related to the wash-out of biomass. In the present investigation, textile dyeing effluent and tapioca starch wastewater at various proportions was deployed. Advantage of combining the effluents was the $\mathrm{pH}$ gets neutralized, therefore no need of adding caustic/lime. The sago effluent was utilized as co-substrate to enhance the degradation of textile dye-house effluent which is recalcitrant in nature. There is no requirement of separate treatment plant to treat both the industrial effluent. The determination of kinetic constants of a bioprocess is a useful tool to be able to describe and predict the performance of the system. Therefore, the aim of this paper is to determine the process kinetics of anaerobic digestion and to compare kinetics among the models applied for the describing the substrate removal kinetics of UASB reactor treating simulated and real textile dyeing wastewater.

DOI: $10.9790 / 264 X-03045765 \quad$ www.iosrjournals.org $57 \mid$ Page


Biomass

\section{Materials And Methods}

The methanogenic granular sludge with unidentified microorganisms used in this experiment was procured from the anaerobic digester treating tapioca starch effluent at Salem, Tamilnadu, India. Before loading the reactor, granular sludge was clearly washed, filtered through a fine mesh ASTM 16 to reduce all the floating and suspended inorganic mineral contents. The volatile suspended solids content of the sludge was $60000 \mathrm{mg} \mathrm{L}$ ${ }^{1}$ (APHA 2005).

\section{Wastewater}

Real untreated wastewater from starch industry and textile dyeing industry was collected at Salem, Tamilnadu, India. Ten samples were collected from each industries for duration of three months and the mean values of the parameters have been tabulated in Table 1. The analysis of the wastewater was carried out according to standard methods (APHA, 2005).

Table 1 Characteristics of wastewaters

\begin{tabular}{llll}
\hline S.No. & Parameters* & Textile dyeing effluent & Sago Effluent \\
\hline 1 & $\mathrm{pH}$ & 12.8 & 4.5 \\
2 & Total Suspended Solids & 420 & 640 \\
3 & Total Dissolved Solids & 3520 & 1200 \\
4 & Chlorides & 1520 & 400 \\
5 & Sulphates & 180 & 123 \\
6 & BOD & 175 & 2400 \\
7 & COD & 1600 & 6000 \\
\hline$*$ All values except $\mathrm{pH}$ are in $\mathrm{mgL}^{-1}$ & &
\end{tabular}

\section{Experimental Setup}

A UASB reactor was fabricated to study the operational and performance characteristics. The volumetric ratios of acidogenic (Phase 1) and methanogenic (Phase 2) reactors were 1:4. The first phase was an acidogenic reactor (300 $\mathrm{mm}$ inner diameter and $820 \mathrm{~mm}$ height) made up of plexi-glass with working volume of $56 \mathrm{~L}$ and second phase was a stainless steel methanogenic reactor (350 mm inner diameter and $2400 \mathrm{~mm}$ height) with working volume of $230 \mathrm{~L}$. The untreated real effluent was fed into the acidogenic reactor followed by methanogenic reactor. Sampling ports were provided at various heights of reactor approximately $400 \mathrm{~mm}$. On the top of the reactor, GLSS was attached. The Gas-Liquid-Solid Separator (GLSS) was attached at top of the reactor, consisted of an inverted conical funnel at top of the water column for the collection of biogas. In addition to the GLSS arrangement, a packed medium consisting of a PVC spirals with size of $26 \mathrm{~mm}$, surface area $500 \mathrm{~m}^{2} \mathrm{~m}^{-3}$ and void ratio $87 \%$ has been provided for a height of $200 \mathrm{~mm}$ located at $1770 \mathrm{~mm}$ from the bottom of the reactor. These spirals will retain the biomass in addition will give a polishing effect to the effluent. The sludge granules trapped in GLSS and the spirals will return to the reactor as soon as the gas entrapped inside the granules was released. Biogas generated was measured using wet gas flow meter. After stabilizing the reactor, studies were conducted under the steady state conditions. The reactor was operated under room temperature $\left(30 \pm 2{ }^{0} \mathrm{C}\right)$ at different Hydraulic Retention Time (HRT) of 36, 30, 24 and $18 \mathrm{~h}$. The pH, TDS and temperature of both the reactors were monitored continuously at every 15 minutes by programmable logic control (PLC).

\section{Analytical procedures}

The treated and untreated samples were analyzed for $\mathrm{pH}, \mathrm{COD}$ and colour removal, VFA and alkalinity as per Standard Methods for Examination of Water and Wastewater (APHA 2005). Colour removal was estimated by monitoring the Optical Density (OD) of the samples using UV-vis spectrophotometer (HITACHI U2001) at $600 \mathrm{~nm}$. COD was monitored by using closed reflux titrimetric method. VFA and Alkalinity was also estimated by titrimetric method. Before analysis, all samples were filtered through $0.45 \mathrm{~mm}$ filters to remove suspended matters.

\section{Reactor performance}

\section{Result And Discussions}

The UASB reactor was operated with real textile dye and sago wastewater with optimum mixing ratio (70:30) (Senthilkumar et al. 2010) at four different HRTs in order to obtain overall kinetic coefficients for different models at steady-state conditions. The results obtained under steady-state condition during the reactor operation at four different HRTs are summarized in Table 2. The COD removal efficiency in acidogenic and methanogenic reactor was in the range of 20-35\% and 76-85\% respectively. Colour removal efficiencies in acidogenic and methanogenic reactor were in the range of 35-45\% and 65-74\% respectively. The overall COD and colour removal efficiency of real wastewaters in two-phase upflow anaerobic sludge blanket reactor was $90.1 \%$ and $85.42 \%$ at $24 \mathrm{~h}$ of HRT. The biogas production at $24 \mathrm{~h}$ HRT was $312 \mathrm{l} / \mathrm{d}$. The pH in the 
methanogenic outlet was in the range of 7.29-7.67. The VFA in acidogenic and methanogenic reactors were in the range of 738-746 mg/l and $56 \mathrm{mg} / \mathrm{l}$ respectively and VFA concentration is increased in both reactors when HRT is decreased. The methanogenic reactor effluent alkalinity and VFA/Alk ratio is in the range of 934-966 $\mathrm{mg} / \mathrm{l}$ and 0.057-0.059 respectively. VFA/Alk ratio is increased when HRT is decreased. Volatile Fatty Acid (VFA)/Alkalinity ratio can be used as a measure of process stability. In this study in methanogenic reactor the $\mathrm{pH}$ and VFA concentration was under stable condition according to Snadhya and Swaminathan (2006). The optimal $\mathrm{pH}$ could be explained by the neutralization of hydrogen anions being released from the volatile fatty acid together with the carbonates dissociated from the carbonic acid with the bicarbonate alkalinity inside the UASB reactor (Razo- Flores et al., 1997). The maximum biogas production of $356 \mathrm{~L} / \mathrm{d}$ was achieved at $18 \mathrm{~h}$ of HRT.

Table 2 Experimental data obtained for Pilot scale two-phase UASB reactor under steady state conditions at four different HRTs.

\begin{tabular}{|c|c|c|c|c|c|c|c|c|}
\hline \multirow[t]{2}{*}{ Parameter } & \multicolumn{8}{|c|}{ HRT (h) } \\
\hline & 4.5 & 18 & 6 & 24 & 7.5 & 30 & 9 & 36 \\
\hline & Aci. & Meth. & Aci. & Meth. & Aci. & Meth. & Aci. & Meth. \\
\hline $\mathrm{pH}$ & 6.32 & 7.29 & 6.85 & 7.52 & 6.75 & 7.61 & 7.14 & 7.67 \\
\hline Inlet COD (mg/l) & 4480 & 3280 & 4880 & 3200 & 4640 & 3520 & 4720 & 3760 \\
\hline Outlet COD (mg/l) & 3280 & 560 & 3200 & 480 & 3520 & 720 & 3760 & 880 \\
\hline COD removal $(\%)$ & 32.78 & 82.92 & 34.42 & 85 & 24.13 & 79.54 & 20.33 & 76.59 \\
\hline $\begin{array}{l}\text { Influent Colour } \\
\lambda \max @ 600 \mathrm{~nm}\end{array}$ & 0.295 & 0.186 & 0.295 & 0.164 & 0.294 & 0.177 & 0.294 & 0.191 \\
\hline $\begin{array}{l}\text { Effluent Colour } \\
\lambda \max @ 600 \mathrm{~nm}\end{array}$ & 0.186 & 0.065 & 0.164 & 0.043 & 0.177 & 0.058 & 0.191 & 0.059 \\
\hline Colour removal $(\%)$ & 36.95 & 65.05 & 44.41 & 73.78 & 39.79 & 67.23 & 35.03 & 69.11 \\
\hline $\operatorname{Biogas}(\mathrm{L} / \mathrm{d})$ & & 356 & & 312 & & 244 & & 225 \\
\hline VFA $\left(\mathrm{mgCH}_{3} \mathrm{COOH} / \mathrm{l}\right)$ & 744 & 56 & 738 & 56 & 746 & 56 & 746 & 56 \\
\hline $\begin{array}{l}\text { Alkalinity } \\
\left(\mathrm{mg} \mathrm{CaCO}_{3} / 1\right)\end{array}$ & 561 & 946 & 566 & 966 & 542 & 956 & 575 & 934 \\
\hline
\end{tabular}

\section{Haldane model}

In order to acquire the kinetic coefficients of Haldane model is plotted in Figure 1 and 2 . For acidogenic reactor the values of kinetic coefficients obtained from Figure 1 are $\mathrm{K}_{\mathrm{s}}=683.51 \mathrm{mg} / \mathrm{L}$ and $\mathrm{K}_{\mathrm{i}}=3865.48 \mathrm{mg} / \mathrm{L}$ on account of larger values of $\mathrm{K}_{\mathrm{i}}$, indicating no inhibition effect on the growth rate of microorganisms. The values of $\mathrm{a}, \mathrm{b}$ and $\mathrm{c}$ are found to be $0.013,50.14$ and 34347 respectively with high correlation coefficients of $\left(\mathrm{R}^{2}\right)$ 0.96. For methanogenic reactor the values of kinetic coefficients obtained from Figure 2 are $K_{s}=422.43 \mathrm{mg} / \mathrm{L}$ and $K_{i}=559.16 \mathrm{mg} / \mathrm{L}$ on account of larger values of $\mathrm{K}_{\mathrm{i}}$, indicating no inhibition effect on the growth rate of microorganisms. The values of $\mathrm{a}, \mathrm{b}$ and $\mathrm{c}$ are found to be $0.034,19$ and 8031 respectively with high correlation coefficients of $\left(R^{2}\right) 0.962$.

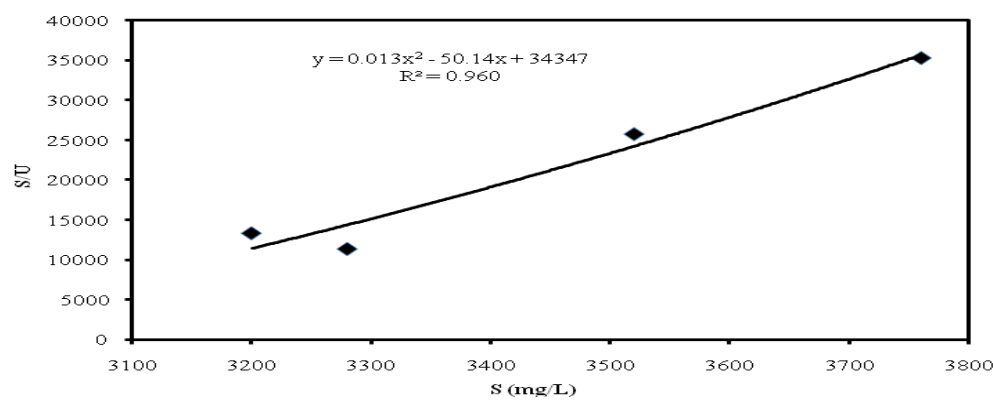

Fig. 1 Determination of half velocity saturation constant $K_{s}$ and inhibition constant $K_{i}$ for Haldane model (Acidogenic reactor)

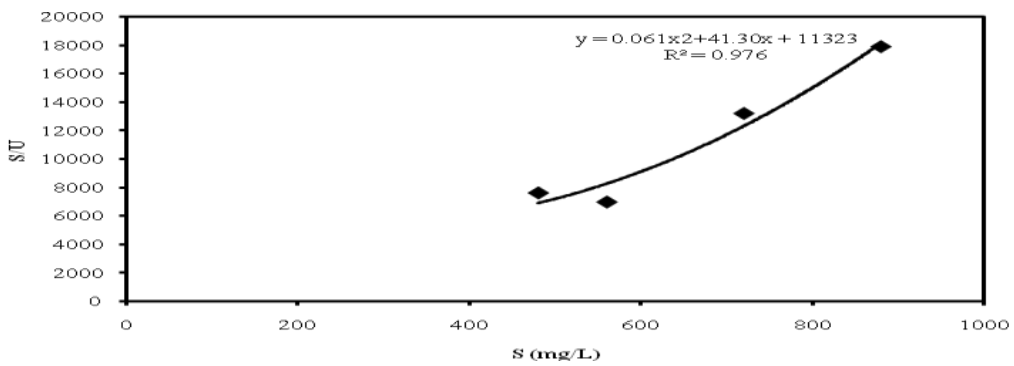

Fig. 2 Determination of half velocity saturation constant $\mathrm{K}_{\mathrm{s}}$ and inhibition constant $\mathrm{K}_{\mathrm{i}}$ for Haldane model (Methanogenic reactor) 


\section{Modified Stover-Kicannon model}

The modified Stover-Kincannon model was applied to experimental results from the continuously operated two-phase upflow anaerobic sludge blanket reactor for decolourization and degradation of combined textile dye and sago wastewater, kinetic constants for COD removal were determined at different hydraulic retention times. In addition, there are kinetic models developed for organic substance removal in continuously operated anaerobic reactors (APHA-AWWA, 2005). Figures 3 and 4 indicates the plot of COD loading V/( $\left(\mathrm{QS}_{0}\right)$ versus COD removal rate $\mathrm{V} /\left[\mathrm{Q}\left(\mathrm{S}_{0}-\mathrm{S}\right)\right]$ of acidogenic and methanogenic reactor. From the figure 3 slope and intercept of a best-fit line $\left(\mathrm{R}^{2}=0.977\right)$, kinetic constants for COD removal in acidogenic reactor were determined as $\mathrm{R}_{\max }=2.36 \mathrm{gL}^{-1} \mathrm{~d}^{-1}$ and $\mathrm{K}_{\mathrm{B}}=30.3 \mathrm{gL}^{-1} \mathrm{~d}^{-1}$, respectively. From the figure 4 slope and intercept of a best-fit line $\left(\mathrm{R}^{2}=0.989\right)$, kinetic constants for COD removal in methanogenic reactor were determined as $\mathrm{R}_{\max }=3.48 \mathrm{gL}^{-1} \mathrm{~d}^{-1}$ and $\mathrm{K}_{\mathrm{B}}=7.77 \mathrm{gL}^{-1} \mathrm{~d}^{-1}$, respectively. The kinetic values obtained using acidogenic reactor are comparable with the kinetic constant $K_{\mathrm{B}}$ and $R_{\max }$ are $12.9 \mathrm{gL}^{-1} \mathrm{~d}^{-1}$ and $37.7 \mathrm{gL}^{-1} \mathrm{~d}^{-1}$ obtained by Kapdan (2005) for anaerobic packed bed reactor treating simulated textile dye wastewater.

Therefore the rate expression for COD in acidogenic reactor takes the following form:

$$
\frac{Q\left(S_{0}-S\right)}{V}=\frac{2.36\left(Q S_{0} / V\right)}{30.3+\left(Q S_{0} / V\right)}
$$

The rate expression for COD in methanogenic reactor takes the following form:

$$
\frac{Q\left(S_{0}-S\right)}{V}=\frac{3.48\left(Q S_{0} / V\right)}{7.77+\left(Q S_{0} / V\right)}
$$

and effluent $\mathrm{COD}$ concentration of acidogenic reactor can be predicted by rearranging the Eq. (1)

$$
S=S_{0}-\frac{2.36 S_{0}}{30.3+\left(Q S_{0} / V\right)}
$$

Effluent COD concentration of acidogenic reactor can be predicted by rearranging the Eq. (2)

$$
S=S_{0}-\frac{3.48 S_{0}}{7.77+\left(Q S_{0} / V\right)}
$$

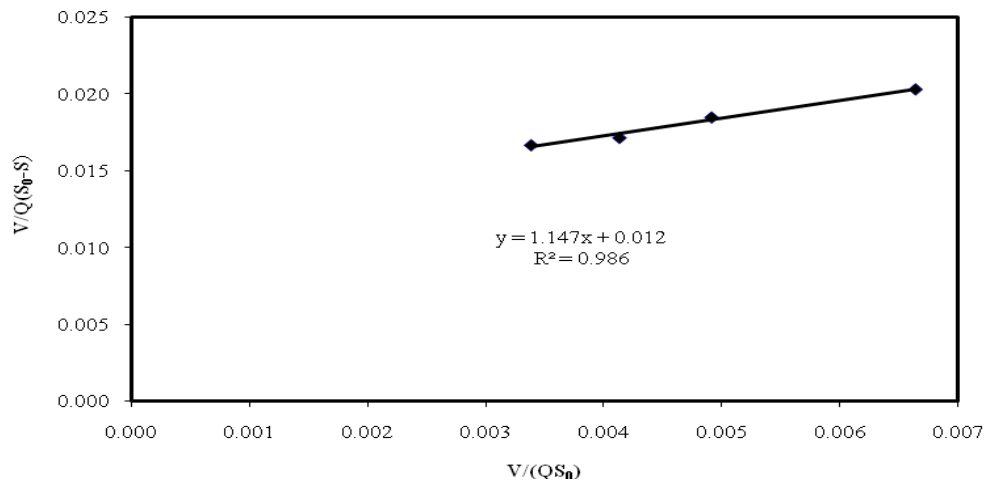

Fig. 3 Stover-Kicannon model plot for acidogenic reactor

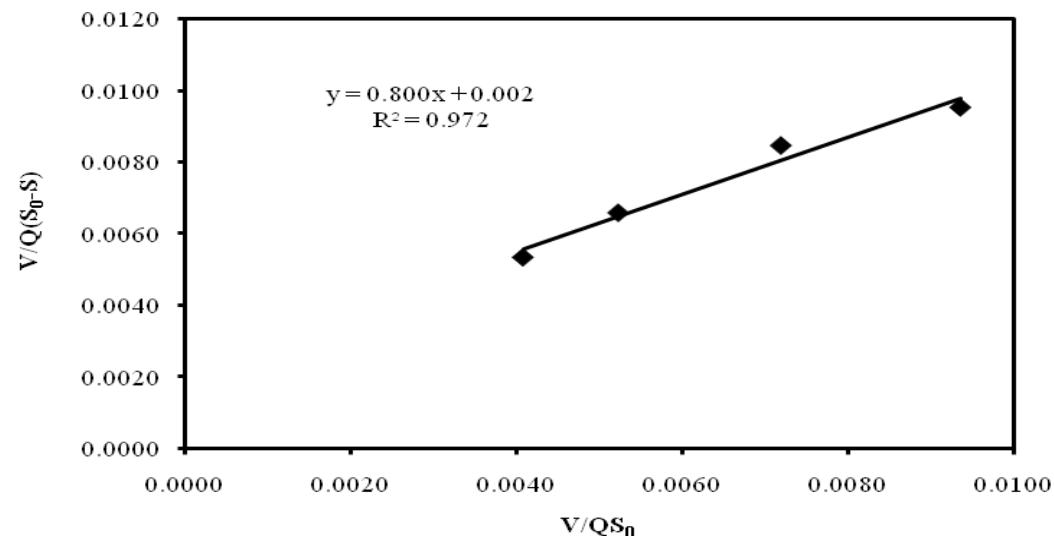

Fig. 4 Stover-Kicannon model plot for methanogenic reactor 


\section{Grau second-order multicomponent substrate removal model}

In order to determine the kinetic co-efficient $\left(\mathrm{a}, \mathrm{b}\right.$ and $\mathrm{k}_{\mathrm{s}}$ ) was plotted in Figures 5 and 6. From Figure 5 the values of $a$, and $b$ were found to be 0.841 and 6.936 with high correlation coefficients of $\left(R^{2}\right) 0.949$. The multicomponent substrate removal rate constant $\left(\mathrm{k}_{\mathrm{s}}\right)$ for acidogenic reactor was then calculated from the equation $\mathrm{a}=\mathrm{S}_{0} /\left(\mathrm{k}_{\mathrm{s}} \mathrm{X}\right)$ as 0.212 per day. From Figure 6 the values of $\mathrm{a}$, and $\mathrm{b}$ were found to be 0.197 and 1.42 with correlation coefficients of $\left(\mathrm{R}^{2}\right)$ 0.993. The multicomponent substrate removal rate constant $\left(\mathrm{k}_{\mathrm{s}}\right)$ for methanogenic reactor was then calculated from the equation $\mathrm{a}=\mathrm{S}_{\mathrm{o}} /\left(\mathrm{k}_{\mathrm{s}} \mathrm{X}\right)$ as 0.418 per day. The values of second order multi-component substrate removal rate constant $\mathrm{k}_{\mathrm{s}}$ for both acidogenic and methanogenic reactor was comparable with Isik and Sponza (2005) $\left(\mathrm{k}_{\mathrm{s}}=0.337\right)$ indicating substrate removal for each unit of microorganism depending on second order substrate removal rate constant $\left(\mathrm{k}_{\mathrm{s}}\right)$.

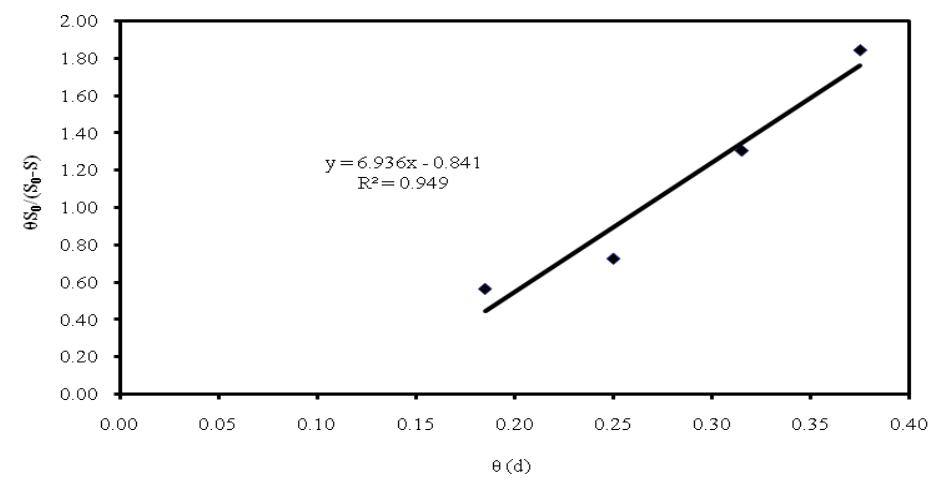

Fig. 5 Determination of kinetic constants $\left(a, b\right.$ and $\left.k_{\mathrm{s}}\right)$ for Grau second order multicomponent substrate removal mode (Acidogenic reactor).

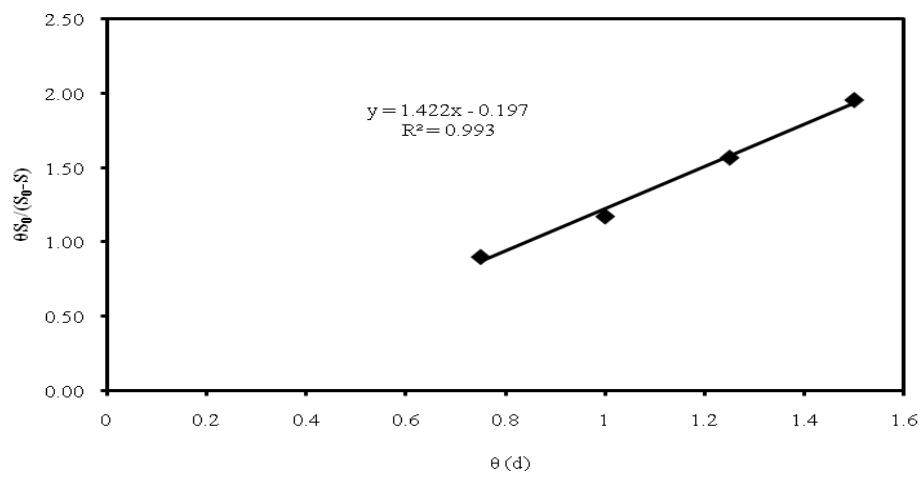

Fig. 6 Determination of kinetic constants $\left(a, b\right.$ and $k_{\mathrm{s}}$ ) for Grau second order multi-component substrate removal mode (Methanogenic reactor).

\section{Evaluation of the kinetic models}

From the engineering point of view, development of kinetic model is a useful tool in designing and optimization of the process by reducing extensive and complex experimental data to simple and convenient mathematical expression. All kinetic coefficients calculated from models are summarized in Table 3 with correlation coefficients. The kinetic data showed that Stover-Kincannon, Grau second order multi-component substrate removal kinetics and Haldane model were more appropriate than the other models for predicting the performance of the pilot scale two phase hybrid UASB reactors when the regression coefficients and kinetic coefficients were compared. The Tables $4 \mathrm{a}, 4 \mathrm{~b}$ and $4 \mathrm{c}$ summarizes the constants determined from the applicable models in previous studies. In this study, the determined Haldane kinetic coefficients $\left(\mathrm{K}_{\mathrm{i}}=3865.4 \mathrm{mg} / \mathrm{L}\right)$ for acidogenic reactor is comparable with the kinetic coefficient $\left(\mathrm{K}_{\mathrm{i}}=3636.36 \mathrm{mg} / \mathrm{L}\right)$ obtained by Bhunia and Ghangrekar (2008). In case of Grau second order model the $k_{s}$ (see Table 4a) values obtained in this study was similar to the $\mathrm{k}_{\mathrm{s}}$ value $\left(0.337 \mathrm{~d}^{-1}\right)$ found by Isik and Sponza (2005) treating simulated textile dye wastewater using UASB reactor, the $\mathrm{k}_{\mathrm{s}}$ value $\left(0.354 \mathrm{~d}^{-1}\right)$ obtained by Bhunia and Ghangrekar (2008) treating synthetic sucrose wastewater using UASB reactor and also the $\mathrm{k}_{\mathrm{s}}$ value $\left(0.227 \mathrm{~d}^{-1}\right)$ obtained by Ubay (1994) treating municipal wastewater in UASB reactor. Whereas higher $\mathrm{k}_{\mathrm{s}}$ values are obtained by Ozturk et al. (1998), Buyukkamaci and Felibeli (2002), Sandhya and Swamynathan (2006), Sandhya et al. (2008), Sponza and Ulukoy (2008) compared to the $\mathrm{k}_{\mathrm{s}}$ values obtained in this study. The possible reason for differences may be variation in reactor configuration, wastewater characteristics and microorganism used in the study. The modified Stover-Kincannon model suggests that the substrate removal rate is affected by the organic loading rate entering 
to the reactor as described. Kinetic coefficients of this model $\left(R_{\max }, K_{\mathrm{B}}\right)$ were higher than the data obtained in other studies as seen in Table $4 \mathrm{~b}$. Whereas the Stover-Kincannon kinetic coefficients $R_{\max }$ and $K_{B}(3.48$ and 7.77) obtained in this study for methanogenic reactor was similar to the $R_{\max }$ and $K_{B}$ (7.5 and 8.2) obtained by Isik and Sponza (2005). For anaerobic systems a review of common substrate utilization kinetic models was carried out by Kuroda et al., (1993), and also by Mata-Alvarez and Cecchi (1990). The Monod model is most widely used for UASB reactors and for industrial effluents (Castillo et al., 1999). In this study, however, it was found that the Monod and Contois model was not appropriate for interpreting the kinetic data of the UASB reactor treating combined real textile and sago wastewater. On the account of poor correlation $\left(\mathrm{R}^{2}<0.3\right)$ with the data set Monod and Contois equation have not been considered for the estimation of kinetic constants. The models applied in this study were also evaluated by comparing the predicted COD values with the tentative values obtained from this continuous operation of pilot-scale UASB reactor. The COD values predicted with the Stover-Kincannon and Grau second order models have a high correlation with actual COD concentrations measured from the pilot scale two phase hybrid UASB reactor as shown in Figs. 7 and 8. In conclusion, based on the kinetic studies, it appears that the kinetic coefficients obtained from the anaerobic treatment of combined real textile dyeing and sago wastewater, satisfies with the Stover-Kincannon, and Grau second order multicomponent substrate kinetic models. Although several studies relevant to anaerobic treatment of some industrial wastewaters and also simulated textile dye wastewater were reported in literature, none of the studies contained a kinetic relevant to two phase anaerobic reactors treating a combined real textile dyeing and sago wastewater. As seen in Table 3, a Grau second order kinetic model gives nearly the same correlation as the Stover-Kincannon. This result is not surprising because two models are very similar as mentioned below:

Second order linearized equation could be transformed to the modified Stover-Kincannon model by dividing $S_{\mathrm{o}}$ each part the equation.

$$
\frac{V}{Q \times\left(S_{0}-S\right)}=\frac{V}{Q \times S_{0}}+\frac{1}{k_{s} \times X}
$$

If Eq. (5) is simulated to the modified Stover-Kincannon model, the following equation can be obtained: $\mathrm{K}_{\mathrm{B}}=\mathrm{R}_{\max }$

The calculated kinetic parameters from the plots of both models are appropriate to the values calculated from the equations given above. As a result of this similarity, the two models have the same sensitivity in order to obtain the kinetic coefficients from the plots when the regression coefficients of the graphs are compared. The similar results were obtained by Isik and Sponza (2005) and Sandhya et al. (2008).

\section{Conclusions}

In this study, the kinetics of UASB reactors treating real textile dyeing wastewater with sago wastewater as co-substrate was investigated using different models such as Monod, Contois, Haldane, Grau second order and modified Stover-Kincannon. On the account of poor correlation $\left(\mathrm{R}^{2}<0.3\right)$ with the data set Monod and Contois equation have not been considered for the estimation of kinetic constants. Among the other three kinetic models, Grau second order model and Stover- Kincannon model were observed to be the preeminent model for predicting the performance of two phase hybrid UASB reactors for treating combined real textile dyeing and sago wastewater with higher average regression coefficients $\left(R^{2}=0.979\right)$. The results of kinetic studies obtained from pilot-scale experiments can be used for estimating treatment efficiency of fullscale reactors with the same operational conditions.

Table 3 Kinetic parameters of UASB reactor treating textile dyeing and sago wastewater

\begin{tabular}{|c|c|c|c|c|c|}
\hline \multirow{2}{*}{$\begin{array}{l}\text { Kinetic models } \\
\text { Pilot scale Acidogenic reactor } \\
\text { Haldane }\end{array}$} & Kinetic parameters & \multirow{2}{*}{$\begin{array}{l}\text { Values } \\
0.013\end{array}$} & \multicolumn{3}{|c|}{ Regression Coefficient $\left(R^{2}\right)$} \\
\hline & a & & & 0.96 & \\
\hline & $\mathrm{b}$ & & 50.14 & & 0.96 \\
\hline & c & & 34347 & & 0.96 \\
\hline & $\mu_{\max } \quad$ (per day) & & 0.019 & & 0.96 \\
\hline & $\mathrm{Ks}(\mathrm{mg} / \mathrm{L})$ & & 683.5 & & 0.96 \\
\hline & $\mathrm{Ki}(\mathrm{mg} / \mathrm{L})$ & & 3865.4 & & 0.96 \\
\hline \multirow[t]{2}{*}{ Grau second order } & a (per day) & & 0.841 & & 0.949 \\
\hline & $\begin{array}{l}\mathrm{b} \text { (dimensionless) } \\
\mathrm{k}_{\mathrm{s}} \text { (perday) }\end{array}$ & 6.936 & 0.212 & 0.949 & 0.949 \\
\hline Modified Stover-Kincannon & $\begin{array}{l}\mathrm{K}_{\mathrm{B}}(\mathrm{g}(1 \text { per day })) \\
\mathrm{R}_{\max }(\mathrm{g} \text { COD }(1 \text { per day }))\end{array}$ & $\begin{array}{c}6.06 \\
41\end{array}$ & & $\begin{array}{l}0.955 \\
0.955\end{array}$ & \\
\hline \multirow{7}{*}{$\begin{array}{l}\text { Pilot scale Methanogenic reactor } \\
\text { Haldane }\end{array}$} & & & & & \\
\hline & a & 0.034 & & 0.962 & \\
\hline & $\mathrm{b}$ & & 19 & & 0.962 \\
\hline & c & & 8031 & & 0.962 \\
\hline & $\mu \max$ (per day) & 0.0526 & & 0.962 & \\
\hline & $\mathrm{Ks}(\mathrm{mg} / \mathrm{L})$ & & 422.43 & & 0.962 \\
\hline & $\mathrm{Ki}(\mathrm{mg} / \mathrm{L})$ & & 559.16 & & 0.962 \\
\hline \multirow[t]{3}{*}{ Grau second order } & a (per day) & & 0.197 & & 0.993 \\
\hline & $\mathrm{b}$ (dimensionless) & 1.422 & & 0.993 & \\
\hline & $\mathrm{k}_{\mathrm{a}}$ (per day) & & 0.418 & & 0.993 \\
\hline \multirow[t]{2}{*}{ Modified Stover-Kincannon } & $\mathrm{K}_{\mathrm{B}}(\mathrm{g}(1$ per day $))$ & 16.12 & & 0.983 & \\
\hline & $R_{\max }(\mathrm{g} C O D$ (1 per day)) & 23.17 & & 0.983 & \\
\hline
\end{tabular}


Table 4a Comparison of Grau second order kinetic constants

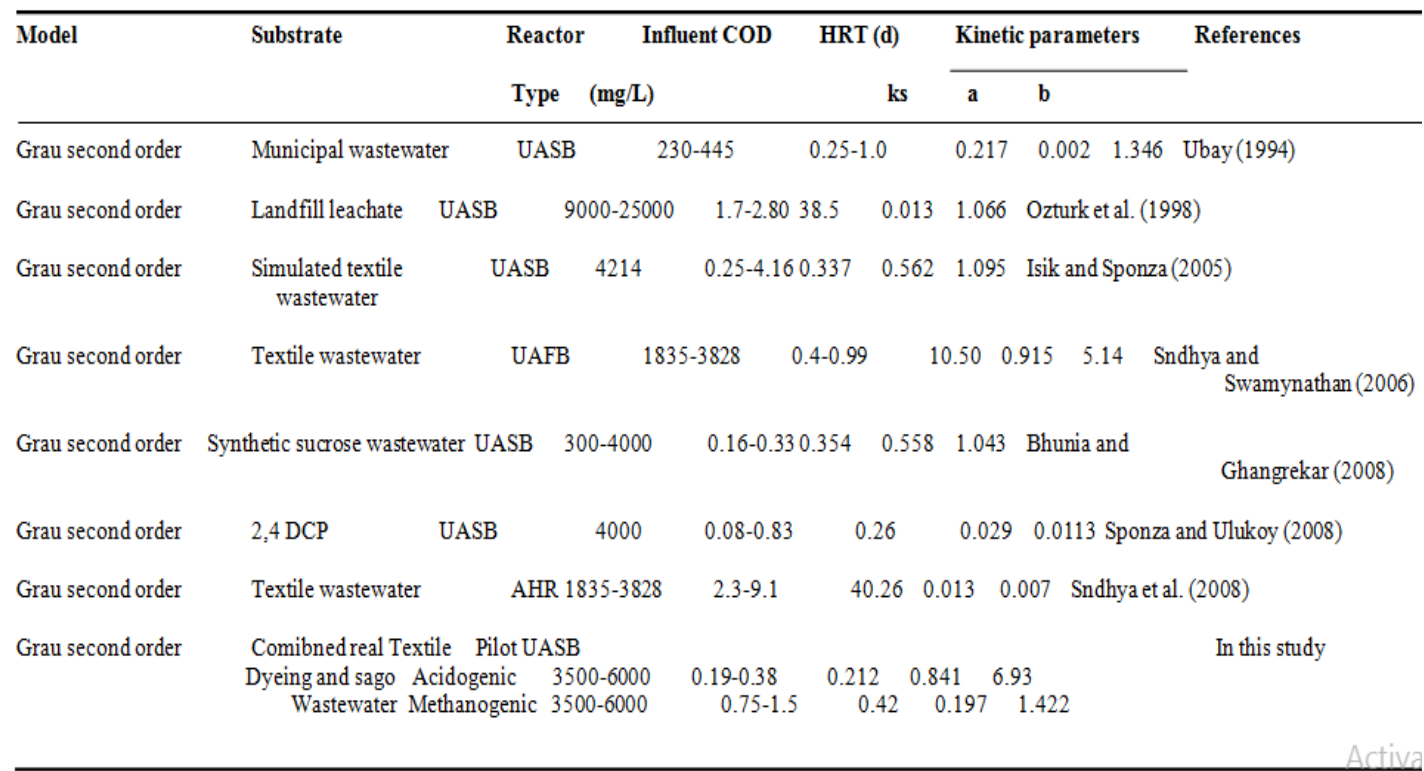

Table 4b Comparison of modified Stover-Kicannon kinetic constants

\begin{tabular}{|c|c|c|c|c|c|c|c|c|c|}
\hline \multirow[t]{2}{*}{ Model } & \multirow[t]{2}{*}{ Substrate } & & \multirow{2}{*}{$\begin{array}{l}\text { Reactor } \\
\text { Type }\end{array}$} & \multirow{2}{*}{$\begin{array}{c}\text { Influent COD } \\
(\mathrm{mg} / \mathrm{L})\end{array}$} & \multirow[t]{2}{*}{ HRT (d) } & \multicolumn{3}{|c|}{ Kinetic parameters } & \multirow[t]{2}{*}{ References } \\
\hline & & & & & & $\operatorname{Rmax}$ & $\mathbf{K}_{\mathrm{B}}$ & & \\
\hline Modified Stover-Kicannon & $\begin{array}{l}\text { Simulated textile } \\
\text { wastewater }\end{array}$ & & UASB & 4214 & $0.25-4.16$ & 7.5 & & 8.2 & Isik and Sponza (2005) \\
\hline Modified Stover-Kicannon & $\begin{array}{r}\text { Simulated Textile } \\
\text { wastewater }\end{array}$ & & UAFB & $1835-3828$ & $0.4-0.99$ & 31.69 & 45.37 & \multicolumn{2}{|c|}{$\begin{array}{l}\text { Sndhya and } \\
\text { Swaminathan (2006) }\end{array}$} \\
\hline Modified Stover-Kicannon & $2,4 \mathrm{DCP}$ & UASB & 4000 & $0.08-0.8$ & 0.0098 & 0.01 & Sponza a & and Ulu & lkoy (2008) \\
\hline Modified Stover-Kicannon & $\begin{array}{c}\text { Comibned real Textile } \\
\text { Dyeing and sago } \\
\text { Wastewater }\end{array}$ & Pilot $\mathrm{U}$ & $\begin{array}{l}\text { ASB } \\
\text { idogenic } \\
\text { thanogenic }\end{array}$ & $\begin{array}{r}3500-6000 \\
3500-6000\end{array}$ & $\begin{array}{l}0.19-0.38 \\
0.75-1.5\end{array}$ & $\begin{array}{l}2.36 \\
3.48\end{array}$ & 7.77 & $\begin{array}{l}\text { In thi } \\
30.30\end{array}$ & is study \\
\hline
\end{tabular}

Table 4c Comparison of Haldane kinetic constants

\begin{tabular}{|c|c|c|c|c|c|c|c|c|c|}
\hline \multirow[t]{2}{*}{ Model } & \multirow[t]{2}{*}{ Substrate } & \multirow{2}{*}{$\begin{array}{c}\text { Reactor } \\
\text { Type }\end{array}$} & \multirow{2}{*}{$\begin{array}{c}\text { Influent COD } \\
\qquad(\mathrm{mg} / \mathrm{L})\end{array}$} & \multirow{2}{*}{$\begin{array}{r}\text { HRT (d) } \\
\text { a }\end{array}$} & \multicolumn{4}{|c|}{ Kinetic parameters } & \multirow[t]{2}{*}{ References } \\
\hline & & & & & b & $\mathbf{c}$ & $\mathrm{Ks}$ & $\mathbf{K i}$ & \\
\hline Haldane & Synthetic wastewater & UASB & $300-4000$ & $0.16-0.33$ & 0.0005 & 51.82 & 2304.2 & 167.23636 .36 & $\begin{array}{l}\text { Bhunia and } \\
\text { Ghangrekar (2008) }\end{array}$ \\
\hline \multicolumn{9}{|c|}{ Haldane Comibned real Textile Pilot UASB } & \multirow[t]{2}{*}{ In this study } \\
\hline & $\begin{array}{l}\text { Dyeing and sago } \\
\text { Wastewater Meth }\end{array}$ & $\begin{array}{r}\text { Acidogenic } \\
\text { nogenic } 3500\end{array}$ & $\begin{array}{r}3500-6000 \\
-6000\end{array}$ & $\begin{array}{rr}0.19-0.38 & 0 \\
5-1.5 & 0.034\end{array}$ & 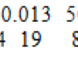 & $\begin{array}{l}50.1^{3} \\
8031^{3}\end{array}$ & $\begin{array}{r}34347 \\
422.43\end{array}$ & $\begin{array}{l}683.5 \quad 3865.4 \\
3 \quad 559.2\end{array}$ & \\
\hline
\end{tabular}

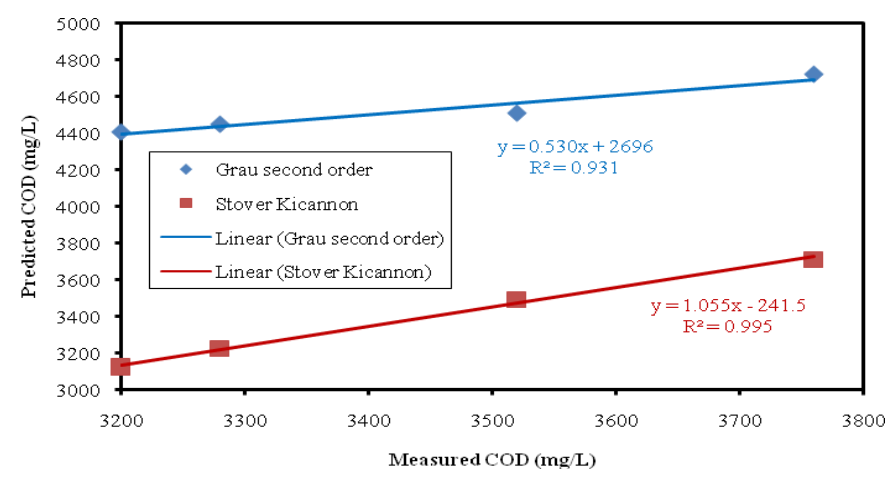

Fig 7 Comparison of the predicted and the actual COD values from the pilot-scale acidogenic UASB reactor. 


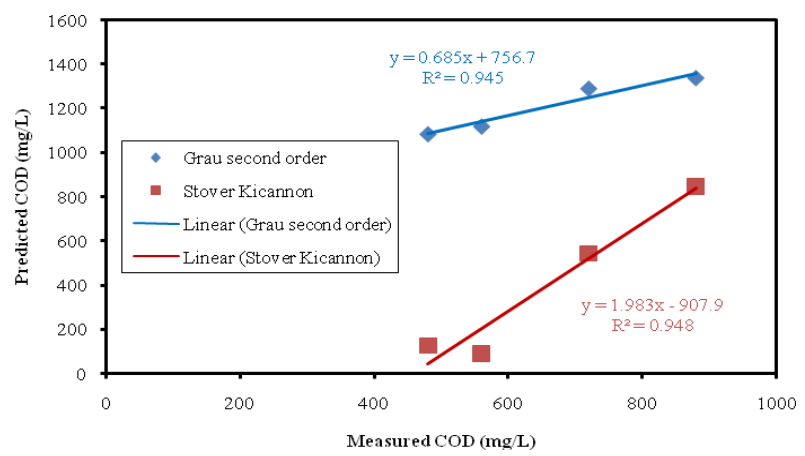

Fig 8 Comparison of the predicted and the actual COD values from the pilot-scale methanogenic UASB reactor.

References

[1] APHA-AWWA (2005) Standard methods for water and wastewater. $20^{\text {th }}$ ed. American Public Health Assoc/American Water Works Assoc. Washington DC, USA.

[2] Buzzini AP, Sakamoto IK, Varesch MB, Pires EC (2006) Evaluation of the microbal diversity in an UASB reactor treating from an unbleached pulp plant. Process Biochem 41: 168-176.

[3] Carliell CM, Barclay SJ, Buckley CA (1996) Treatment of exhausted reactive dyebath effluent using anaerobic digestion: Laboratory and full-scale trials. Water SA 22:225-33.

[4] Castillo A, Llabres P, Mata-Alvarez J (1999) Kinetic study of a combined anerobic-aerobic system for treatment of domestic sewage. Water Res 33(7):1742-7.

[5] Chen YR, Hashimoto AG (1980) Substrate utilisation kinetic model for biological treatment processes. Biotechnol Bioeng 22:208195.

[6] Delee W, O'Neill C, Hawkes FR, Pinheiro HM (1998) Anaerobic treatment of textile effluents: a review. J. Chem. Technol. Biotechnol. 73:323-335.

[7] Grady CPL, Harlow LJ, Riesing RR (1972) Effects of growth rate and influent substrate concentration on effluent quality from chemostats containing bacteria in pure and mixed culture. Biotechnol Bioeng 14:391-410.

[8] Grau P, Dohanyas M, Chudoba J (1975) Kinetic of multicomponent substrate removal by activated sludge. Water Res 9:337-42.

[9] Isik M, Sponza DT (2003) Aromatic amine degradation in an UASB/CSTR sequential system treating Congo Red dye. J Environ Sci Health Part A 38(10):2301-15.

[10] Isik M, Sponza DT (2005) Substrate removal kinetics in an upflow anaerobic sludge blanket reactor decolorising simulated textile wastewater. Process Biochemistry 40: 1189-1198.

[11] Iza J, Colleran E, Paris JM, Wu WM (1991) International workshop on anaerobic treatment technology for municipal and industrial wastewaters: summary paper. Water Sci Technol 24(8):1-16.

[12] Kalyuzhnyi S, Sklyar V (2000) Biomineralisation of azo dyes and their breakdown products in anaerobic-aerobic hybrid and UASB reactors. Water Sci Technol 41(12):23-30.

[13] Kapdan IK (2005) Kinetic analysis of dyestuff and COD removal from synthetic wastewater in an anaerobic packed column reactor. Process Biochemistry Process Biochemistry 40: 2545-2550.

[14] Kuai L, De Vreese I, Vandevivere P (1998) GAC-amended UASB reactor for the stable treatment of toxic textile wastewater. Environ Technol 19:1111-7.

[15] Kuroda M, Sakakibara Y, Jin W, Erjie Y, Baozhen W, Quanda Y (1993) A therotical consideration of the kinetics of multiple substrate utilization in anaerobic digestion. Water Sci Technol 28(7):77-80.

[16] Lettinga G, Vanvelsen AFM, Hobina SM, Zee W, Klapswik A. Use of the upflow sludge blanket (USB) reactor concept for biological wastewater treatment. Biotechnol Bioeng 1980;22(4):699-734.

[17] Malta-Alvarez J, Cechi F. Kinetic models applied to anaerobic biodegradation of complex organic matter. In: Kamely D, Chakrabardy A, Omenn GS, editors. Biotecnology and biodegradation advances in applied biotechnology, vol. 4 (Chapter 17). The Woodlands, TX: Portfolio Pub; 1990. p. 317-44.

[18] Manu B, Chaudhari S. Anaerobic decolorization of simulated textile wastewater containing azo dyes. Bioresour Technol 2002;82:225-31.

[19] Manu, B., Chaudhari, S. (2003). Decolorization of indigo and azo dyes in semicontinuous reactors with long hydraulic retention time. Process Biochemistry 38(8), 1213-1218

[20] Mendez-Paz, D., Omil, F., Lema, J.M. (2005). Anaerobic treatment of azo dye acid orange 7under fed-batch and continuous conditions. Water Res. 39: 771-778.

[21] O'Neill C, Hawkes FR, Esteves SRR, Hawkes DL, Wilcox SJ. Anaerobic and aerobic treatment of a simulated textile effluent. J Chem Technol Biotechnol 1999; 74:993-9.

[22] Ozturk, I., Altinbas, M., Arikan, O., Demir, A. (1998). Anaerobic UASBR treatment of young landfill leachate. In: Proceedings of the First International Workshop on Environmental Quality and Environmental Engineering in the Middle East Region. Konya, Turkey.

[23] Pagga, U., Brown, D., 1986. The degradation of dyestuffs: Part II Behaviour of dyestuffs in aerobic biodegradation tests. Chemosphere 15, 479-491.

[24] Ramakrishna, K.R., Viraraghavan, T. (1997). Dye removal using low cost adsorbents. Water Sci. Technol. 36: 189-196.

[25] Razo-Flores, E., Luijten, M., Swarts, H., Lettinga, G., Field, J. (1997). Detoxification and partial mineralization of the azo dye mordant orange 1 in a continuous upflow anaerobic sludge-blanket reactor. Appl. Microbiol. Biotechnol. 47: 83 - 90.

[26] Sandhya, S., Sarayu, K., Swaminathan, K. (2008). Detrmination of kinetic constants of hybrid textile wastewater treatment system. Bioresource Technology 99: 5793-5797.

[27] Sandhya, S., Swaminathan, K. (2006). Kinetic analysis of treatment of textile wastewater in hybrid column upflow anaerobic fixed bed reactor. Chemical Engineering Journal 122: 87-92. 
[28] Sarasa, J., Roche, M.P., Ormad, M.P., Gimeno, E., Puig, A. (1998). Treatment of a wastewater resulting from dyes manufacturing with ozone and chemical coagulation. Water Res. 32: 2721-2727.

[29] Sen S., Demirer G.N. (2003) Anaerobic treatment of real textile wastewater with a fluidized bed reactor. Water Research 37, 18681878 .

[30] Sponza DT, I,s1k M. Decolorization and azo dye degradation by anaerobic/aerobic sequential process. Enzyme Microb Technol 2002;31(1-2):102-10.

[31] Sponza, D.T., Ulukoy, A. (2008). Kinetics of carbonaceous substrate in an upflow anaerobic sludge blanket (UASB) reactor treating 2,4 dichlorophenol (2,4 DCP). Journal of Environmental Management 86: 121-131.

[32] Tan NCG, Prenafeta-Boldu FX, Opsteeg JL, Lettinga G, Field JA. Biodegradation of azo dyes in cocultures of anaerobic granular sludge with aerobic aramatic amine degrading enrichment cultures. Appl Microbiol Biotechnol 1999;51:865-71.

[33] Ubay, G. Anaerobic treatment of municipal wastwaters, Ph.D. Thesis, Istanbul Technical University, Turkey, 1994.

[34] Yu H, Wilson F, Tay J. Kinetic analysis of an anaerobic filter treating soybean wastewater. Water Res 1998;32(11):3341-52.

[35] Zaoyan YKS, Guangliang S, Fan Y, Jinshan D, Huanian M. Anaerobic-aerobic treatment of a dye wastewater by combination of RBC with activated sludge. Water Sci Technol 1992;26(9-11):2093-6.

IOSR Journal of Biotechnology and Biochemistry (IOSR-JBB) is UGC approved Journal with S1. No. 4033, Journal no. 44202.

G.Gnanapragasam. "Evaluation of kinetic models for tearing textile dyeing wastewater using UASB reactor." IOSR Journal of Biotechnology and Biochemistry (IOSR-JBB) 3.4 (2017): 5765. 